\title{
Fond Memories of our Mentor J. David Hellums, Annals of Biomedical Engineering
}

There are giants amongst us in many fields of science, individuals who have led the way endowed with variable combinations of intellect, tenacity, and charisma that enabled them to deliver outsized contributions to discovery and invention. David Hellums certainly exemplified these qualities in making his mark in cardiovascular mechanics and transport. $\mathrm{He}$ had a knack for assembling experimental devices that delivered highly dynamic readouts of blood cell function and combined this with practical mathematical models to provide novel insights to a diverse set of phenomena including oxygen transport by hemoglobin and platelet aggregation in linear shear fields. David motivated his students and colleagues to push the boundaries of biophysical measurement in order to gain molecular scale insight into how nature solved the problems of transport in the circulation. His work in these settings made him one of the pioneers of the field of what is now called cellular engineering. What set David apart from his colleagues was his easy manner; he was a quintessential gentleman with an easy Texas drawl who was quick to share great stories of sailing in the Gulf of Mexico on his Catamaran with family and friends. He conducted himself in the same genteel way whether he was teaching a class of undergraduates transport phenomena or raising funds with the Houston elite as Dean of Engineering. There was one place where David was not always gentle-on the tennis court. He loved competing in the game and was both excellent and crafty. One of us (LVM) played both singles and doubles with and against David for nearly 30 years. Between points, he would often move slowly looking tired, and then crush a forehand by you as play began.

David was the most generous mentor that any of us have experienced. His tall stature never got in the way, he always managed to adjust his wonderful deep brow gaze to engage and share his immense intellectual gifts to all students and faculty lucky enough to have roamed the halls of the George R. Brown School of Engineering during his reign.

\section{ScotT I. Simon}

Department of Biomedical Engineering

University of California, Davis

Antonios G. Mikos

Department of Biomedical Engineering

Rice University

LARRY V. MCINTIRE

Bioengineering

Georgia Institute of Technology 